\title{
Early Impact of COVID-19 Outbreak on the Availability of Cornea Donors: Warnings and Recommendations
}

This article was published in the following Dove Press journal: Clinical Ophthalmology

\author{
Mario Toro (D) ${ }^{1,2}$ \\ Tomasz Choragiewicz' \\ Chiara Posarelli $\mathbb{D}^{3}$ \\ Michele Figus $\mathbb{D}^{3}$ \\ Robert Rejdak' \\ On Behalf of European \\ COVID-19 Cataract Group \\ (\#EUROCOVCAT)
}

'Department of General Ophthalmology, Medical University of Lublin, Lublin, Poland; ${ }^{2}$ Faculty of Medical Sciences, Collegium Medicum Cardinal Stefan Wyszyński University, Warsaw, Poland; ${ }^{3}$ Department of Surgical, Medical, and Molecular Pathology, and of the Critical Area, University of Pisa, Pisa, Italy
Correspondence: Mario Toro Department of General Ophthalmology, Medical University of Lublin, Lublin, Poland

Tel +48608047052

Fax +48815326149

Email toro.mario@email.it

\begin{abstract}
Keratoplasty is one of the irreplaceable treatment options for corneal diseases. Currently, there is no evidence to substantiate that harvested corneal grafts from COVID-19 patients can contain SARS-CoV-2 virus and lead to a systemic infection. Although the risk of transmission through corneal stromal tissue is low, it potentially exists. Lack of clinical data, unclear potential of donor-derived infection and non-established recommendations for transplantation during the COVID-19 pandemic have resulted in a dramatic reduction in the number of keratoplasty and cornea donors at ophthalmology departments and eye banks. To eliminate the risk of infection of recipients and medical personnel, we suggest that the blood samples of all donors should be screened with RT-PCR tests and nasopharyngeal swabs should be taken. In addition, a chest CT scan should be performed if the circulation is maintained. Moreover, the donors' clinical and epidemiological medical history must be screened for typical symptoms and potential contact with SARS-CoV-2 carriers to reduce the risk of transmission. The Guidelines of the Eye Bank Association of America (EBAA), Global Alliance of Eye Bank Associations (GAEBA) and European Association of Tissue Banks provide useful recommendations to eliminate the risk of transmission according to previous experiences based on similar viruses.
\end{abstract}

Keywords: COVID-19 pandemic, keratoplasty, transplant, ophthalmology, RT-PCR blood test, chest CT scan

Corneal blindness is the fourth leading cause of blindness worldwide; however, nearly $80 \%$ of all corneal blindness cases are avoidable and reversible. To date, keratoplasty is the most commonly performed allogenic transplant worldwide, with a success rate of $90-95 \% .^{1}$ Thus, the treatment of acute corneal diseases, mainly trauma or infectious keratitis, is an urgent or emergent care issue that can involve aggressive surgery, requiring the availability of optimal eye-banked tissues, by trained personnel. ${ }^{1}$ Reports from the Eye Bank Association of America (EBAA) show an increase in the number of whole globe and cornea donations in recent years, with a $+1.9 \%$ change in 2019 compared to 2018 . $^{2}$

In response to the COVID-19 pandemic, ophthalmology departments have been either placed in lockdown or reorganized into COVID-19 units ${ }^{3}$ to cater to the lack of infrastructure and resources in many regions. It has been reported that patient encounters have drastically decreased, by $57 \%$ in cardiology-related cases and by $55 \%$ in breast health-related cases, with a $37 \%$ decline in cancer care. ${ }^{4}$ Moreover, the percentage of ophthalmological treatments decreased by about $81 \%$ in March and 
April 2020 in comparison with the same period in $2019 .{ }^{4}$ This includes a $97 \%$ reduction in cataract surgery volume - the largest reduction of any surgical routine procedure until its total blockage and a delay of urgent proceduresdue to the need for prioritizing emergencies. ${ }^{4-6}$ In several countries, reduced access to emergency care for diseases, such as retinal detachment, thrombotic events and trauma, as well as reduced cornea donations, have been observed (almost $60 \%$ less than in the same period of 2019 at the Eye Bank of Lublin, Poland). ${ }^{7}$ This has resulted in a significant reduction, leading to a complete suspension of transplantations in many departments. This process, if not reversed, could lead to disability and may severely affect access to sight-saving cures for many patients.

Moreover, the increasing number of reported COVID19 cases after solid organ transplantation emphasizes an urgent need for protocol modifications based on donorrecipient selection, postoperative screening and treatment. ${ }^{8}$ Indeed, all urgent surgeries involving the use of donor tissues could be a potential route of virus transmission for both medical personnel and recipients.

We have agreed to consult with a group of surgeons and experts from 10 European countries, called the European COVID-19 Cataract Group (EUROCOVCAT). We have organized call conferences and shared experiences and perspectives on the current scenario. An indepth analysis of the current situation in eye care has been merged with updated literature and available recommendations from scientific ophthalmic societies and healthcare institutions.

Currently, there is no evidence to substantiate that harvested corneal grafts from COVID-19 patients can contain SARS-CoV-2 and lead to a systemic infection. Although the risk of transmission through corneal stromal tissue is low, it potentially exists owing to the presence of ACE2 and TMPRSS2 expressions in cornea. ${ }^{9,10}$ For these reasons, stable recommendations on corneal transplant procedures are highly demanded but still controversial.

A survey conducted in the USA revealed the heterogeneous guidelines and approaches among different transplant centers, but COVID-19 is, undoubtedly, a major threat in transplantation. The survey also revealed the variations in screening, testing algorithms, clinical practice and policies, and the differences in transplanted organs and types of transplant. ${ }^{11}$ The lowest rates of reduction in organ transplantations were observed for heart, lung and deceased donor kidney, whereas the highest rates of reduction were observed for transplantations of live donor kidney, live donor liver and pancreas. Suspected COVID-19 testing algorithms for deceased donors and recipients also varied among respondents. Almost half of respondents suggested simultaneous full respiratory viral panel (RVP) with COVID-19 testing. Others suggested that common algorithms were isolated COVID-19 testing (in almost 30\%) and reflex COVID-19 testing if influenza, respiratory syncytial virus or full RVP tests were negative. ${ }^{11}$ The most frequently proposed tests for deceased donors were the nasopharyngeal nucleic acid test and bronchoalveolar lavage nucleic acid test, which is the rarest blood nucleic acid test. However, in almost $4 \%$ of respondents, no test was proposed. More than half of respondents reported changes in outpatient practices, from stopping or reducing visits to switching to telemedicine. ${ }^{11}$

The specifics of keratoplasty differ from transplantation of other organs, especially with respect to the general condition of the recipient. Thus, some analogies and conclusions should be made and applied in ophthalmology. In the COVID-19 pandemic, safety as a principal goal of any medical intervention (primum non nocere) is axiomatic. The risk of contamination of the recipient must be eliminated, considering deficient knowledge about donor-derived infection and imperfections in diagnostic tests. ${ }^{12}$ Although the existing protocols of tissue preparation provide full protection for medical personnel and recipients, additional security measures must be applied. The epidemiological history of the donor, potential contact with SARS-CoV-2 carriers and onset of typical COVID-19 symptoms must be screened. In all donors, a nasopharyngeal swab RT-PCR test for SARS-CoV-2 should be mandatory. Asymptomatic or subclinical patients with SARS-CoV-2 infections pose particular risks for recipients, especially when reputable RTPCR tests for SARS-CoV-2 do not rule out the possibility of COVID-19 virus infection. The false-negative tests (in the range of $17-63 \%$ of cases $^{13,14}$ ) can be a consequence of many factors: poor quality of the specimen containing insufficient patient material, late or very early collection of specimens with respect to infection stage, or mishandling or inappropriate shipping of specimens. ${ }^{15}$ To eliminate the risk of potential transmission, special efforts should be undertaken with respect to the technical aspects of nasopharyngeal swabs. To determine the presence of an adequate amount of material in the sample, a PCR testing human DNA target should be included as a control. ${ }^{15}$ In addition, in donors with preserved circulation, chest CT scans should be performed, even if the donor has a negative clinical and epidemiological history. 
EBAA has listed some of the potential viruses that can transmit via ocular tissues (West Nile virus, Vaccinia virus, Ebola virus and Zika virus). This is because of their high prevalence in the donor pool and their fatal or life-threatening status. Such infection could result in permanent impairment or damage of a body function, or could necessitate medical or surgical intervention to preclude it. However, there is insufficient evidence to substantiate such transmission. ${ }^{16}$ A single post-mortem RT-PCR for SARS-CoV-2 should eliminate the risk of transmission in a deceased donor.

The COVID-19 pandemic has recently forced governing bodies to revise their recommendations for corneal transplantation (Table 1). ${ }^{17-19}$ Such recommendations should eliminate the risk of transmission, according to previous experiences based on similar viruses.

Table I Guidelines of the Eye Bank Association of America (EBAA), Global Alliance of Eye Bank Associations (GAEBA) and European Association of Tissue Banks

\begin{tabular}{|c|c|c|}
\hline $\begin{array}{l}\text { Eye Bank Association of America } \\
\text { (EBAA) })^{17}\end{array}$ & $\begin{array}{l}\text { Global Alliance of Eye Bank } \\
\text { Associations (GAEBA) }\end{array}$ & European Association of Tissue Banks ${ }^{19}$ \\
\hline $\begin{array}{l}\text { Recommendation to exclude/defer potential } \\
\text { donors for ocular tissue who met one or } \\
\text { more of the following criteria: } \\
\text { I. Tested positive for or diagnosed with } \\
\text { COVID- I } 9 \text { within the past } 2 \text { months. } \\
2 \text {. Acute respiratory illness (fever }>100.4^{\circ} \mathrm{F} \\
\left(38^{\circ} \mathrm{C}\right) \text { and at least one severe common } \\
\text { symptom of respiratory disease with no other } \\
\text { etiology that fully explains the clinical } \\
\text { presentation within the last } 28 \text { days. } \\
\text { 3. Close contact with a person who has } \\
\text { confirmed COVID-19 infection or with a } \\
\text { person under investigation (PUI) (as defined } \\
\text { by the CDC) within the last } 28 \text { days. } \\
4 \text {. Travel to or transit through a foreign } \\
\text { country identified by the CDC as a level } 2 \text { or } \\
3 \text { travel risk within the last } 28 \text { days. } \\
\text { 5. ARDS (acute respiratory distress } \\
\text { syndrome), pneumonia or pulmonary } \\
\text { computed tomography (CT) scanning showing } \\
\text { "ground glass opacities" (regardless of } \\
\text { whether another organism is present) within } \\
\text { the last } 28 \text { days. }\end{array}$ & $\begin{array}{l}\text { I. Person with confirmed or suspected } \\
\text { coronavirus infection (including healthcare } \\
\text { workers) } \\
\text { Must not donate if: } \\
\text { (a) Less than I4 days since resolution of } \\
\text { symptoms due to confirmed coronavirus } \\
\text { infection } \\
\text { (b) Awaiting test results for suspected } \\
\text { coronavirus infection. } \\
\text { Discretionary acceptance: } \\
\text { (a) Confirmed infection. If more than I4 days } \\
\text { have passed since resolution of symptoms } \\
\text { (b) Respiratory failure not related to viral } \\
\text { infection, or where COVID-19 was ruled out } \\
\text { following testing. } \\
\text { 2. Contact with a confirmed or suspected case } \\
\text { of coronavirus infection. } \\
\text { Must not donate if: } \\
\text { Less than I4 days from the first day of contact } \\
\text { with an individual having confirmed or } \\
\text { suspected infection. } \\
\text { Discretionary acceptance: } \\
\text { (a) If more than I4 days since the first day of } \\
\text { contact with an individual having confirmed or } \\
\text { suspected infection, and the donor remained } \\
\text { well with no symptoms of coronavirus } \\
\text { infection } \\
\text { (b) If less than I4 days and the donor } \\
\text { remained well with no symptoms of } \\
\text { coronavirus infection-subject to individual } \\
\text { risk assessment } \\
\text { (c) Donors without respiratory symptoms } \\
\text { who are not suspected to have, and have not } \\
\text { been tested for COVID-I } 9 \text { infection, and who } \\
\text { were in intensive care units with patients who } \\
\text { had been tested for COVID- } 9 \text { infection and } \\
\text { subsequently moved to isolation facilities } \\
\text { following confirmation of infection-subject } \\
\text { to individual risk assessment. }\end{array}$ & $\begin{array}{l}\text { Deceased donation: } \\
\text { - Deceased donors with active confirmed } \\
\text { COVID-19 at the time of death are not } \\
\text { eligible for tissue donation. } \\
\text { - Deceased donors who have recovered from } \\
\text { COVID- } 19 \text { may donate tissues if they tested } \\
\text { negative for the presence of SARS-CoV-2 } \\
\text { RNA in upper respiratory tract specimens at } \\
\text { least I4 days before death or if they became } \\
\text { asymptomatic at least } 28 \text { days before death. } \\
\text { - Tissues should not be collected from } \\
\text { deceased donors who are without symp- } \\
\text { toms or diagnosis of COVID-19, and who } \\
\text { have lived in or visited areas of sustained } \\
\text { community transmission of the virus unless: } \\
\text { - Procured tissues are disinfected, sterilized } \\
\text { or microbially inactivated using a procedure } \\
\text { validated for enveloped viruses } \\
\text { - Donors tested negative for the presence of } \\
\text { SARS-CoV-2 RNA in upper or lower } \\
\text { respiratory tract specimens collected within } \\
72 \text { hours before procurement. }\end{array}$ \\
\hline
\end{tabular}




\section{Ethical Approval}

This article does not contain any studies with human participants or animals performed by any of the authors.

\section{Acknowledgments}

The authors are grateful to the following members of the EUROCOVCAT (European COVID-19 Cataract Group): Antoine Pierre Brézin, Michael Burdon, Arthur Bernard Cummings, Ozlem Evren Kemer, Boris Edvard Malyugin, Isabel Prieto, Miguel Angel Teus, Daniele Tognetto, and Riikka Törnblom, for their suggestions and for providing data during the revision process of the manuscript.

\section{Author Contributions}

All authors made a significant contribution to the work reported, whether that is in the conception, study design, execution, acquisition of data, analysis and interpretation, or in all these areas; took part in drafting, revising or critically reviewing the article; gave final approval of the version to be published; have agreed on the journal to which the article has been submitted; and agree to be accountable for all aspects of the work.

\section{Funding}

There is no funding source.

\section{Disclosure}

The authors declare that they have no conflicts of interest for this work.

\section{References}

1. Singh R, Gupta N, Vanathi M, Tandon R. Corneal transplantation in the modern era. Indian J Med Res. 2019;150(1):7-22.

2. Available from: https://restoresight.org/who-we-are/statistics/. Accessed August 17, 2020.

3. Jørstad ØK, Moe MC, Eriksen K, Petrovski G, Bragadóttir R. Coronavirus disease 2019 (COVID-19) outbreak at the Department of Ophthalmology, Oslo University Hospital, Norway. Acta Ophthalmol. 2020;98(3):e388-e389.
4. Analysis: Ophthalmology Lost More Patient Volume Due to COVID19 Than Any Other Specialty. Strata decision technology. Available from: https://eyewire.news/articles/analysis-55-percent-fewer-ameri cans-sought-hospital-care-in-march-april-due-to-covid-19. Accessed August 17, 2020.

5. Romano MR, Montericcio A, Montalbano C, et al. Facing COVID-19 in ophthalmology department. Curr Eye Res. 2020;45(6):653-658. doi:10.1080/02713683.2020.1752737

6. Xia J, Tong J, Liu M, et al. Evaluation of coronavirus in tears and conjunctival secretions of patients with SARS-CoV-2 infection. $J$ Med Virol. 2020;92(6):589-594. doi:10.1002/jmv.25725

7. Pellegrini M, Roda M, Lupardi E, Di Geronimo N, Giannaccare G, Schiavi C. The impact of COVID-19 pandemic on ophthalmological emergency department visits. Acta Ophthalmol. 2020. doi:10.1111/ aos. 14489

8. Michaels MG, La Hoz RM, Danziger-Isakov L, et al. Coronavirus disease 2019: implications of emerging infections for transplantation. Am J Transplant. 2020.

9. Desautels JD, Moshirfar M, Martheswaran T, Shmunes KM, Ronquillo YC. Risks posed to corneal transplant recipients by COVID-19-affected donors. Ophthalmol Ther. 2020;6:1.

10. Ma D, Chen C, Jhanji V, et al. Expression of SARS-CoV-2 receptor ACE2 and TMPRSS2 in human primary conjunctival and pterygium cell lines and in mouse cornea. Eye (Lond). 2020;7:1-8.

11. Boyarsky BJ, Chiang TP, Werbel WA, et al. Early impact of COVID19 on transplant center practices and policies in the United States. Am J Transplant. 2020.

12. Rosenthal PJ. The importance of diagnostic testing during a viral pandemic: early lessons from novel Coronavirus Disease (COVID19). Am J Trop Med Hyg. 2020.

13. Li Y, Yao L, Li J, Chen L, Song Y, Cai Z, Yang C. Stability issues of RT-PCR testing of SARS-CoV-2 for hospitalized patients clinically diagnosed with COVID-19. J Med Virol. 2020.

14. Wang Y, Kang H, Liu X, Tong Z. Combination of RT-qPCR testing and clinical features for diagnosis of COVID-19 facilitates management of SARS-CoV-2 outbreak. J Med Virol. 2020;92:538-539.

15. Available from: https://apps.who.int/iris/bitstream/handle/10665/331329/ WHO-COVID-19-laboratory-2020.4-eng.pdf. Accessed August 17, 2020.

16. Available from: https://restoresight.org/wp-content/uploads/2019/11/ Med-Standards-October-10-2019.pdf. Accessed August 17, 2020.

17. Eye Bank Association of America. COVID-19 screening recommendations for EBAA member eye banks. Available from: https://restore sight.org/covid-19-updates/. Accessed March 30, 2020.

18. Global Alliance of Eye Bank Associations. ALERT UP-DATE: coronavirus (COVID-2019) and ocular tissue donation. Available from: https://www.gaeba.org/2020/alert-coronavirus-2019-ncov-and-oculartissue-donation/. Accessed March 25, 2020.

19. Available from: https://www.ecdc.europa.eu/sites/default/files/docu ments/COVID\%2019-supply-substances-human-origin-first-update. pdf. Accessed August 17, 2020.
Clinical Ophthalmology

\section{Publish your work in this journal}

Clinical Ophthalmology is an international, peer-reviewed journal covering all subspecialties within ophthalmology. Key topics include: Optometry; Visual science; Pharmacology and drug therapy in eye diseases; Basic Sciences; Primary and Secondary eye care; Patient Safety and Quality of Care Improvements. This journal is indexed on PubMed
Central and CAS, and is the official journal of The Society of Clinical Ophthalmology (SCO). The manuscript management system is completely online and includes a very quick and fair peer-review system, which is all easy to use. Visit http://www.dovepress.com/ testimonials.php to read real quotes from published authors.

\section{Dovepress}

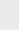

